\title{
IN SILICO ANALYSIS OF XANTHINE OXIDASE INHIBITOR OF ETHYL ACETATE FRACTION OF ETHANOLIC EXTRACT OF STELECHOCARPUS BURAHOL (BL.) HOOK F. AND TH. LEAVES
}

\author{
DINIATIK ${ }^{1,2 *}$, SUWIJIYO PRAMONO ${ }^{1}$, SUGENG RIYANTO ${ }^{1}$ \\ ${ }^{1}$ Department of Pharmaceutical Biology, Faculty of Pharmacy, Universitas Gadjah Mada, Sekip Utara, Jogjakarta, Indonesia. ${ }^{2}$ Department \\ of Pharmaceutical Biology, Faculty of Pharmacy, Universitas Muhammadiyah Purwokerto, Jl. Raya Dukuh Waluh Purwokerto, Indonesia. \\ Email: diniatik@yahoo.com.au
}

Received: 01 November 2016, Revised and Accepted: 08 January 2017

ABSTRACT

Objective: The research was conducted by in silico analysis of xanthine oxidase (XO) inhibitors of volatile compounds from ethyl acetate fraction of ethanolic extract of Stelechocarpus burahol (Bl.) Hook F. and Th. leaves. The objective of the research was to determine the active compounds as a potential inhibitor of XO using in silico screening method.

Methods: The research was conducted using volatile compounds that were obtained by gas chromatography of ethyl acetate fraction of ethanolic extract of $S$. burahol leaves and models of XO inhibitor downloaded via Protein Data Bank with code 3BDJ, The five compounds was performed molecular docking against xanthine oxidase enzyme target using Pyrx.

Results: Volatile compounds in the ethyl acetate fraction of ethanolic extract were 3 heptene, 2,2,4,6,6-pentamethyl (2.15\%), methyl hexadecanoate (4.16\%), ethyl tridecanoate (34.63\%), methyl octadecanoate (7.26\%), and ethyl hexadecanoate (51.8\%). The results showed that three of the chemical compounds have lower free energy value as XO inhibitors than oxypurinol.

Conclusion: They were ethyl tridecanoate, methyl octadecanoate, and ethyl hexadecanoate with free energy $(\Delta \mathrm{G})-10.7,-7.6,-7.1 \mathrm{kcal} / \mathrm{mol}$.

Keywords: Stelechocarpus burahol (Bl.) Hook F. and Th., Xanthine oxsidase, In silico analysis.

(C) 2017 The Authors. Published by Innovare Academic Sciences Pvt Ltd. This is an open access article under the CC BY license (http://creativecommons. org/licenses/by/4. 0/) DOI: http://dx.doi.org/10.22159/ajpcr.2017.v10i5.15970

\section{INTRODUCTION}

Stelechocarpus burahol leaves were used to overcome gout and are capable of lowering cholesterol levels [1]. Fruits of S. burahol also have high vitamin $C$ as efficacious as antioxidants and leaves are now believed to address diabetes [2]. Antioxidant activity using 2,2-diphenyl-1picrylhydrazyl of ethyl acetate extract of the burahol fruits was higher than the isolates of the active fraction from n-butanol extract of burahol flowers [3]. Antihiperurisemia activity of ethanol and hexane extract from burahol leaves were reported equivalent with allopurinol on the xanthine oxidase inhibition test using mice (in vivo test) [4]. Water extract of $S$. burahol leaves possesess the potential of lowering the uric acid level of rats [5] and chicken [6].

Phytochemical analysis of $S$. burahol leaves obtained from some areas reported some chemical constituents such as saponin, alkaloid, tannin, phenolic, flavonoid, triterpenoid, steroid, and glycoside. Tannin content of the $S$. burahol leaves originating from West Java (Bogor and Garut) was undetectable, while $S$. burahol leaves from Central Java all contain tannins [2]. Batubara et al. (2012) [7] reported that $S$. burahol fruits had pharmacological activity as an oral deodorant in vitro and in vivo methods. Oral deodorant composed of some volatile compounds such as eters, aromatic methyl ketones, alcohol esters, and salicylates [8]. Therefore, it is crucial to search volatile compounds of these plants that need to be determined using gas chromatography/ mass spectrophotometry (GC/MS) method. Nakanishi et al. (1990) [9] reported two ester compounds ((Z,E)-2(3,5-dihydroxyphenyl)ethenyl ester and 3-(3,4-dihydroxyphenyl)-2-propenoid acid) as having XO inhibitor. Mirghani et al. (2012) [10] reported that the essential oils of Lemongrass (Cymbopogan citratus) have a XO inhibitor. $\mathrm{XO}$ is an enzyme that is distributed extends from bacteria to humans [11]. $\mathrm{XO}$ is responsible for metabolizing purine bases. XO catalyzes the oxidation of hypoxanthine into xanthine, which is furthermore reduced to uric acid [12]. The accumulation of uric acid in the body results in hyperuricemia and gout [13].

Therefore, this research aims to evaluate the virtual screening as XO inhibitory activity from the compounds in ethyl acetate fraction of ethanolic extract of $S$. burahol leaves, which was compared to oxypurinol (synthetic XOI) based on energy binding.

\section{METHODS}

\section{Plant material preparation}

The plant was identified in the laboratory of Plant Morphology and Plant Taxonomy Faculty of Biology, University of Gadjah Mada, Jogjakarta, and was deposited in the Laboratorium of Biology Pharmacy, Faculty of Pharmacy, Muhammadiyah University of Purwokerto. Materials of this research were $S$. burahol leaves collected from Yogyakarta. The leaves were washed with running water and then dried with natural sunlight under a black cloth. S. burahol leaves were grinded by using a blender.

\section{Extraction}

The powder was extracted by maceration technique for 2 days, with $70 \%$ ethanol; for the first 24 hrs of maceration, ten parts of the solvent were used for one part of the powder. In the second maceration, four parts of the solvent were used for one part of the powder. The combined macerates were evaporated to obtain a thick ethanolic extract.

\section{Fractionation}

The extract $(170 \mathrm{~g}$ ) was hydrolyzed with $400 \mathrm{ml} 1 \mathrm{~N} \mathrm{HCl}$ :methanol $(1: 1)$ at $100^{\circ} \mathrm{C}$ for 30 minutes. The hydrolyzate was fractionated using chloroform and ethyl acetate. The volatile compounds in ethyl acetate were identified by gas chromatography. 
XO inhibitory activity assay

The inhibitory effect on XO was measured spectrophotometrically at $290 \mathrm{~nm}$ under aerobic condition, with some modifications, following the method reported by Ernawati and Susanti (2001) [14]. A well-known XOI, allopurinol $(100 \mu \mathrm{g} / \mathrm{ml})$, was used as a positive control for the inhibition test. Xanthine oxidase activity was determined by adding $200 \mathrm{ml}$ of substrate (xanthine) $0.15 \mathrm{mM}$ in a mixture of $100 \mu \mathrm{l}$ of xanthine oxidase $100 \mathrm{mU} / \mathrm{ml}$ and $724 \mu \mathrm{l}$ of phosphate buffer $\mathrm{pH}$ 7.5. XO activity was determined by observing the rate of formation of uric acid from xanthine by spectrophotometry at a wavelength $(\lambda)$ of $290 \mathrm{~nm}$ from minute 0 up to 3 minutes at a temperature of $25^{\circ} \mathrm{C}$. Data were obtained in the form of rate ( $\Delta$ A290 minutes) [15].

XO inhibitory activity of allopurinol was determined by adding $200 \mu \mathrm{l}$ of allopurinol at a concentration of $10 \mu \mathrm{g} / \mathrm{ml}$ to $100 \mu \mathrm{g} / \mathrm{ml}$ into a mixture of phosphate buffer, xanthine and xanthine oxidase . In the similar way, also the XO inhibitory activity by $200 \mathrm{ml}$ of test solution (carried out using the orientation of concentration $10-100 \mathrm{ug} / \mathrm{ml}$ ) was determined.

\section{GC/MS analysis}

Gas chromatography was determined with $30 \mathrm{~m} \times 0.25 \mathrm{~mm}$ agilent HP 5 MS column. Injection was in the split mode with a 1:33 ratio. The column oven and injector temperatures were $120^{\circ} \mathrm{C}$ and $310^{\circ} \mathrm{C}$, respectively. The linear flow rate of helium gas was $23.7 \mathrm{~cm} / \mathrm{seconds}$. GC/MS analysis was carried out using GC/MS QP010S Shimadzu in the ACQ mode with a mass range of $\mathrm{m} / \mathrm{z} 28-600$.

\section{Processing and data analysis}

The mass spectra from peak chromatogram were analyzed by comparing with the library (NIST62.LIB, WILEY229.LIB) of mass spectra.

\section{Molecular docking}

Ligand reference: A set of reference compounds were obtained by screening an online 3D-mimic database with the following procedure: The target protein (the crystal structure of XO the crystal structure of xanthine oxidase (3bdj) obtained from www.pdb.org. obtained from www.pdb.org [16]. Compounds that would be docked can also be downloaded. Then, they were inputted using Vina.

Molecular screening procedure: All the selected compounds that have a 3D-optimized geometry of the ligand-binding energy is determined with reference to $\mathrm{XO}$ in bovine milk source (3BDJ) by the way of docking using Vina. This is done by loading compounds in the table openbabel in PyRx program and by converting all the files into the extension. pdbqt and then Vina wizard was executed by maximizing grid box to obtain the binding energy in $\mathrm{kcal} / \mathrm{mol}$ units.

\section{RESULT AND DISCUSSION}

S. burahol plants used in the research were determined in the Laboratory of Biology, Faculty of Pharmacy, University of Gadjah Mada. Determination goal is to ensure that the plant in question was correct. Results of determination stated that the plant specimen is true. The determination was based on the book Flora of Java Vol II [17].
In this study, the leaves were collected at the Yogyakarta District, Yogyakarta Province, Indonesia. Extraction method used was maceration, by soaking the crude drug powder with a liquid solvent. In this study, the solvent used is $70 \%$ ethanol. Ethanol $70 \%$ was selected due to a more selective, non-toxic, and neutral ability to prevent the growth of mold and bacteria. The extract obtained was evaporated over a water bath until thick consistency (20.12\%) was obtained.

The inhibitory effects of ethanolic extract of $S$. burahol leaves, chloroform fraction, ethyl acetate fraction, and allopurinol are shown in Table 1.

Determination of the activity of xanthine oxidase inhibitory by using spectrophotometric method. XO activity was determined by observing the rate of formation of uric acid from xanthine at a wavelength of $290 \mathrm{~nm}$. Xanthine has an absorption rate in the ultraviolet wavelength of $260 \mathrm{~nm}$ [19] over a 6-minute uric acid formation reaction kinetics which is linear [20]. In this study, the rate of formation of uric acid linear was 5 minutes. Thus, the determination of uric acid formation was carried out during the first 4 minutes. Ethanol extract possesed inhibiting activity toward XO enzyme (52.11 ug/ml).Antihyperuricemic activity of ethanolic extract of burahol leaves was reported (4). Antioxidant activity of methanolic extract of burahol leaves was reported (1). Ethyl acetate fraction had the higher activity with IC50 was $0.31 \mathrm{ug} / \mathrm{ml}$ than chloroform fraction with IC50 was $9.78 \mathrm{ug} / \mathrm{ml}$. Ethyl acetate fraction had lower activity of $0.31 \mathrm{ug} / \mathrm{ml}$ than chloroform fraction of $9.78 \mathrm{ug} / \mathrm{ml}$. Thus, ethyl acetate fraction was separated and detected by GC/MS. The chromatogram of the separation of the compound of the ethyl acetate fraction is shown in Fig. 1.

Table 1: The xanthine oxidase inhibition of ethanolic extract of $S$. burahol leaves, chloroform fraction, ethyl acetate fraction, and allopurinol

\begin{tabular}{lll}
\hline Concentration $(\mathbf{u g} / \mathbf{m l})$ & \% inhibition & $\left.\mathbf{I C}_{\mathbf{5 0}} \mathbf{( u g} / \mathbf{m l}\right)$ \\
\hline Allopurinol & & \\
0.57 & 37.91 & 4.59 \\
1.43 & 53.59 & $4.29^{*}$ \\
2.86 & 77.12 & $3.16^{* *}$ \\
Ethyl acetate fraction & & \\
0.57 & 49.12 & 0.31 \\
1.14 & 71.93 & \\
2.29 & 80.70 & \\
Chloroform fraction & & \\
10.86 & 45.61 & \\
54.31 & 74.56 & \\
108.62 & 81.58 & \\
Ethanolic extract & & \\
39.81 & 45.67 & \\
79.63 & 60.49 & \\
119.44 & 76.54 & \\
\hline
\end{tabular}

*Septiningsih et al., 2012 [18] **Ernawati and Susanti, 2014 [14],

S. burahol: Stelechocarpus burahol, $\mathrm{IC}_{50}$ : Inhibitory concentration $50 \%$

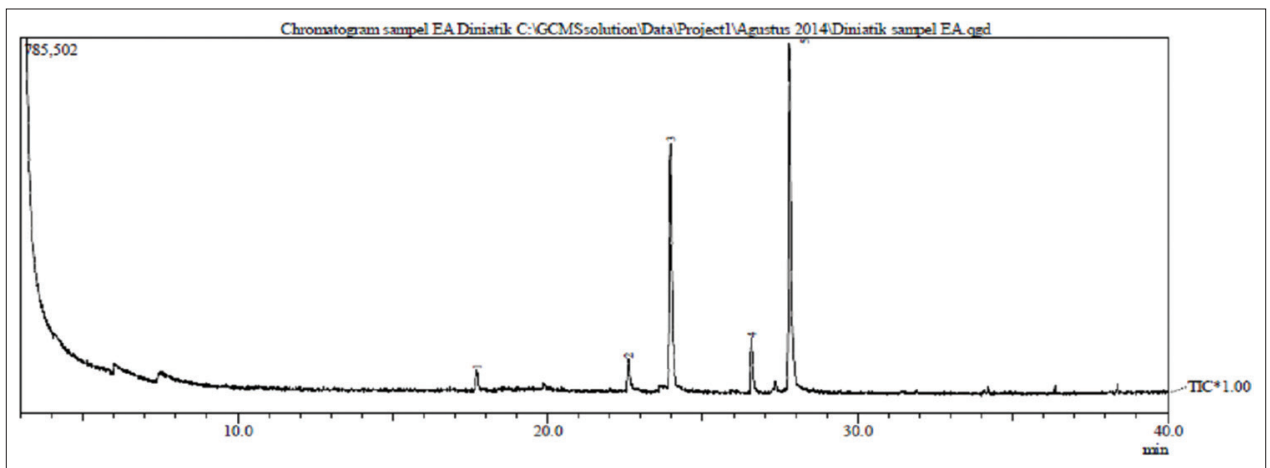

Fig. 1: Gas chromatogram of ethyl acetate fraction of ethanolic extract of Stelechocarpus burahol leaves 
The separation of ethyl acetate fraction obtained five compounds: (1) 3 heptene, 2,2,4,6,6-pentamethyl (2.15\%), (2) methyl hexadecanoate (4.16\%), (3) ethyl tridecanoate (34.63\%), (4) methyl octadecanoate $(7.26 \%)$, and (5) ethyl hexadecanoate $(51.8 \%)$. The major compound was ethyl hexadecanoate, which was an ester compound. Fig. 1 shows the structure of 5 volatile compounds from the ethyl acetate fraction of ethanol extract of $S$. burahol leaves.

Binding energy of five compounds againts XO enzyme were showed in Table 3 below. The retrieved 3 compounds have lower free energy than oxipurinol, so it is suspected that these compounds have inhibitory activity of the enzyme XO better than oxipurinol (Fig. 2). The threedimensional structure of the enzyme 3 BDJ is shown in Fig. 3.

From the five of the volatile compounds from the fraction of ethyl acetate, it can be observed that the four compounds are esters (methyl hexadecanoate [4.16\%], ethyl tridecanoate [34.63\%], methyl octadecanoate [7.26\%], and ethyl hexadecanoate [51.8\%]. Ethyl tridecanoate, methyl octadecanoate, and ethyl hexadecanoate have Gibbs free energy lower than oxipurinol with average free energy $(\Delta \mathrm{G})-10.7,-7.6,-7.1 \mathrm{kcal} / \mathrm{mol}$. The ethyl acetate fraction has potent compounds as inhibitors of the enzyme XO in the form of ester where the compounds ethyl tridecanoate, methyl octadecanoate, ethyl hexadecanoate have a large percentage, ie respectively $34.63 \%$, $7.26 \%, 51.8 \%$ (Table 2). Previous research reported that ethyl acetate extract and ethyl acetate fraction of ethanolic extract from Sonchus arvensis leaves inhibited XO with inhibitory concentration $50 \%\left(\mathrm{IC}_{50}\right.$ ) $15.29 \mathrm{~g} / \mathrm{ml}$ and $16.20 \mathrm{~g} / \mathrm{ml}$, respectively, more potent than ethanolic extract with $\mathrm{IC}_{50} 23.64 \mathrm{~g} / \mathrm{ml}$ [21]. Purwatiningsih et al. (2010) [4] reported that ethanolic extract and hexane extract of $S$. burahol leaves almost have equivalent activity as XO inhibitor with allopurinol. Haddi and Marouf (2015) [22] reported that the crude and ethyl acetate extracts of Pistacia lentiscus leaves had XO inhibitory activity (ethyl acetate fraction with $60.2 \%$, necessary $\mathrm{IC}_{50}$ of XO $\left(\mathrm{IC}_{50}=2.50\right.$ ), Haddi \& Marouf (2015) (22) reported that the crude and ethyl acetate<smiles></smiles>

Fig. 2: Oxypurinol

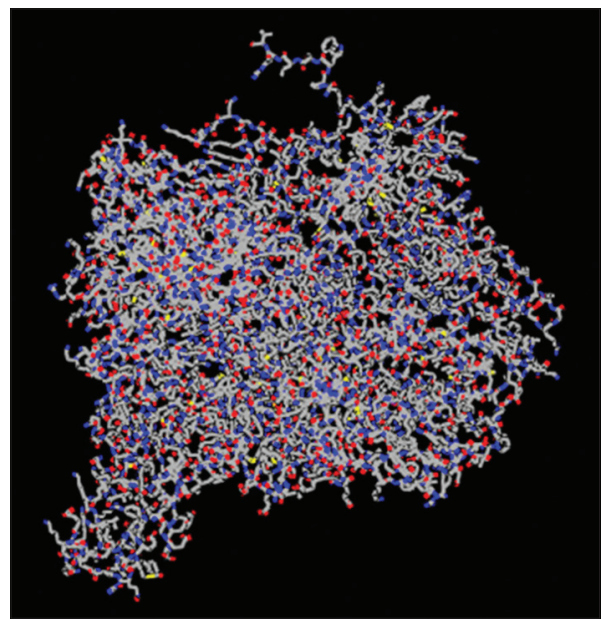

Fig. 3: Xanthine oxidase from bovine milk source (3BDJ)

Table 2: Some volatile constituents of the ethyl acetate fraction of ethanolic extract of $S$. burahol leaves identified by GC/MS

\begin{tabular}{|c|c|c|c|c|c|}
\hline Peak & Retention time & Area \% & Name structure & Similarities' index & Library \\
\hline \multirow[t]{2}{*}{1.} & 17.71 & 2.15 & 3-Heptene, 2,2,4,6,6-pentamethyl & \multirow[t]{2}{*}{78} & \multirow[b]{2}{*}{ NIST62 LIR WULY229 UR } \\
\hline & 22.60 & 4.16 & Methyl hexadecanoat & & \\
\hline 3. & 23.96 & 34.63 & Ethyl & 92 & NIST62.LIB \\
\hline 4. & 26.57 & 7.26 & Methyl octadecanoate & 94 & NIST62.LIB \\
\hline 5. & 27.80 & 51.8 & Ethyl hexadecanoat & 93 & NIST62.LIB, WILEY229.LIB \\
\hline & & & $y^{2} \sim \infty$ & & \\
\hline
\end{tabular}

GC/MS: Gas chromatography/mass spectrophotometry, S. burahol: Stelechocarpus burahol 
Table 3: Binding energy between 5 volatile compounds from the ethyl acetate fraction with BDJ enzyme

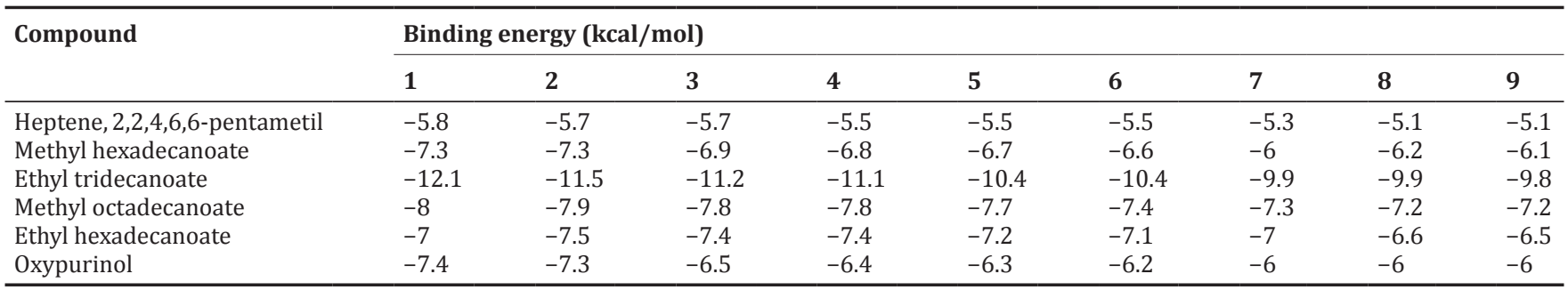

extracts of Pistacia lentiscus leaves had XO inhibitory activity (ethyl acetate fraction with $60.2 \%$, necessary concentration to inhibite $50 \%$ of xanthine oxidase enzyme (IC50) $=2.50$, the crude with $55.3 \%$, IC50 $=2.57$ ).

\section{CONCLUSION}

The volatile contents of the ethyl acetate fraction of $S$. burahol leaves' ethanolic extract are 3 heptene, 2,2,4,6,6-pentamethyl, methyl hexadecanoate, ethyl tridecanoate, methyl octadecanoate, and ethyl hexadecanoate. There are three chemicals that have free energy lower than oxypurinol and which inhibit the activity of the enzyme XO, i.e., ethyl tridecanoate, methyl octadecanoate, and ethyl hexadecanoate with free energy as $(\Delta \mathrm{G})-10.7,-7.6,-7.1 \mathrm{kcal} / \mathrm{mol}$.

\section{REFERENCES}

1. Sunarni T, Pramono S, Asmah R. Antioxidant-free radical scavenging of flavonoid from the leaves of Stelechocarpus burahol (B1.) Hook. F. and Th. Leaves on the body weight ad organ of sparague-dawley rats. Indones J Pharm 2007;18:111-6.

2. Indonesian Spice and Medicinal Crops Research Institute (ISMCRI). Report, Stelechocarpus burahol - Rare Medicinal Plants. Indonesia, Bogor: ISMCRI; 2013

3. Tisnadjaja D, Saliman E, Silvia, Simanjuntak P. Study of Stelechocarpus burahol (B1.) Hook. F. and Th. As an antioxidative compound containing fruit. Biodiversitas 2006;7(2):199-202.

4. Purwantiningsih, Hakim AR, Purwatini I. Antihyperuricemic activity of the kepel (Stelechocarpus burahol (B1.) Hook. F. and Th.) Leaves extract and xanthine oxidase inhibitory study. Int J Pharm Pharm Sci 2010;2:122-7.

5. Susilowati I. Activity Study of Stelechocarpus burahol (B1.) Hook. F. and Th. Leaves to eliminate uric acid content. Skripsi. Yogyakarta, Indonesia: Ahmad Dahlan University; 2000.

6. Hening TH. Effect of Infusa from Stelechocarpus burahol, (BL) Hook. F. and Th. Leaves to serum uric acid level on liver induced chicken. Skripsi. Yogyakarta, Indonesia: Sanata Dharma University; 2002.W

7. Batubara I, Darusman LK, Djauhari E, Mitsunaga T. Potency of kepel (Stelechocarpus burahol) as siclooxigenase-2 inhibitor. J Indones Med Plant 2010;3(2):110-4.

8. Liu X, Williams M, Subramanyam R. Oral Compositions for Reducing
Mouth Odors. US Patent 6,379,652. 2002. Google Patents. Available from: https://www.google.com/patents/US6379652.

9. Nakanishi $\mathrm{T}$, Nishi M. Inada A, Obata $\mathrm{H}$, Tanabe $\mathrm{N}$, Abe $\mathrm{S}$, et al. Two new potent inhibitors of xanthine oxidase from leaves of Perilla frutescens Britton var. Acuta Kudo. Chem Pharm Bull (Tokyo) 1990;38(6):1772-4.

10. Mirghani ME, Liyana Y, Parveen J. Bioactivity analysis of lemongrass (Cymbopogon citratus) essential oil. Int Food Res J 2012;19(2):569-75.

11. Symons MC, Taiwo FA, Petersen RL. Electron addition to xanthine oxidase. An electron spins resonance study of the effects of ionizing radiation. J Chem Soc 1989;12:4063-74.

12. Zarepour M, Kaspari K, Stagge S, Rethmeier R, Mendel R, Bittner F. Xanthine dehydrogenase AtXDH1 from Arabidopsis thaliana is a potent producer of superoxide anions via its NADH oxidase activity. Plant Mol Biol 2010;72(3):301-10.

13. Egwim EC, Vunchi MA, Egwim PO. Comparison of xanthine oxidase activities in cow and goat milks. Biokemistri 2002;17:1-6.

14. Ernawati, Susanti H. In vitro xanthine oxidase inhibition activity of the sarang semut (Myrmecodia tuberosa (non Jack) B1.) ethanol extract. Pharmaçiana 2014;4:15-22.

15. Anonymous. Enzymatic Assay of Xanthine Oxidase (EC 1.1.3.22). Sigma Aldrich, (Procedure from Sigma Aldrich); 1994.

16. Bhatia MS, Ingale $\mathrm{KB}$, Coudhari $\mathrm{PB}$, Zarekar BE, Bhatia NM, Shirekar AS. 3D QSAR: Exploring influence of parameters of pyrazoline analogues on resistant strain of Staphylococcus aureus. Int J Drug Des Discov 2010;1:41-8.

17. Backer CA, Bakhuizen van den Brink RC. Flora of Java: Spermatophytes Only. Vol. I. Netherlands: N.V.P. Noordhoff-Groningen; 1963. p. 3-51, 100-2.

18. Septiningsih U, Susanti H, Widyaningsih W. Xanthine oxidase inhibitory of ethanolic extract of sambiloto root. Pharmaçiana 2012;2(2):153-63.

19. Nagao A, Seki M, Kobayashi H. Inhibition of xanthine oxidase by flavonoids. Biosci Biotechnol Biochem 1999;63(10):1787-90.

20. Van Hoorn DE, Nijveldt RJ, Van Leeuwen PA, Hofman Z, M'Rabet L, De Bont DB, et al. Accurate prediction of xanthine oxidase inhibition based on the structure of flavonoids. Eur J Pharmacol 2002;451(2):111-8.

21. Hendriani R, Sukandar EY, Kusnandaranggadiredja, Sukrasno. In vitro evaluation of xanthine oxidase inhibitory activity of Sonchus arvensis leaves. Int J Pharm Pharm Sci 2014;6(2):501-3.

22. Haddi R, Marouf A. Xanthine oxidase inhibitory effects of Pistacia lentiscus L. Leaves extracts. Int J Pharm Pharm Sci 2015;7(2):34-9. 